\title{
Cooperation in coal research
}

\section{by John Wilson}

BrITAIN and the United States are to share the results of almost all their research into the mining and use of coal. This was decided formally on June 26, when an agreement was signed simultaneously in London by Sir Derek Ezra, Chairman of the National Coal Board (NCB) and in Washington by the Honorable Rogers C. B. Morton, United States Secretary of the Interior. Over the live telephone link from Washington $\mathrm{Mr}$ Morton said that it was "not only feasible but imperative" that the two countries exchange information now. For his part, Sir Derek described the agreement as "about the most comprehensive list that could have been laid down". He emphasised, however, that the agreement should not be seen as being exclusive, and mentioned commitments to other countries.

The full text has not yet been released but fifteen major areas of research are specifically named. These are the gasification, hydrogenation and solvent extraction of the coal; long wall mining techniques (needed in deep mines); automatic cutting machine control; coal preparation techniques; automatic measurement of coal characteristics; effluent control; minestone disposal; noise and dust control; safety research in the workings (degasification, subsidence studies, roof supports, and prevention of spontaneous combustion); air pollution control (treatment of flue gases); open cast mining techniques (including restoration of the site); advanced power systems and fluid bed combustion.

How cooperation on many of these topics should best be established is not yet finalised but further discussions are expected to take place at an international meeting on coal research which is to be held in London in October.

The agreement runs initially for three years and is extended automatically for periods of two years unless one of the parties withdraws. Each side must call for the information it wants and there are provisions in the agreement for the safeguard of patents and the exchange of personnel.

With Sir Derek Ezra in London was Dr William Gouse, Director of the United States Office of Coal Research and Development and Acting Director of the Office of Coal Research. Saying that coal "was something that the United States had discovered last fall" he described its importance to the United States as an energy source of its own from which clean fuel could be prepared. But he said that there was a shortage of people with the appropriate research background to exploit these resources - a weakness in mining technology being the weak link.

As part of President Nixon's drive to make the United States independent of external energy sources by 1980 , the Department of the Interior plans to spend about $\$ 3,500$ million on mining and coal utilisation research over the next five years. And it hopes that this sum will almost be matched by private industry.

Britain will spend a lot less. In plans which Sir Derek Ezra says have been "well received" by the Secretary of State for Energy, Mr Eric Varley, the $\mathrm{NCB}$ is calling for $\$ 100$ million ( $£ 40$ million) to be made available over the same period.

But this disparity in expenditure should not be taken as a measure of each country's contribution to the research agreement. Sir Derek Ezra says that "this agreement will be very much a two-way process. We are not just latching on to a great American effort, we have much to give in return". The NCB's knowledge of the basic processes in coal utilisation methods is sound, he continues, and the United States has the resources to set up the necessary pilot schemes.

The United States is particularly interested in the fluid bed combustion of coal-a technique in which the bed of coal and ash inside a furnace is given the properties of a liquid by the upward passage of air. It hopes to use this method to generate electricity and is spending $\$ 30$ million next year on the building of a pilot plant. Under the agreement just signed, the results from this and other similar pilot projects will be available to Britain.

The United States has only recently discovered that it will have to dig deep for its coal. This is not only to obtain sufficient quantities of high grade coal but also to avoid the wrath of the environment lobby which is violently opposed to strip mining.

Noting that Britain has by far the biggest mining industry in Western Europe, Sir Derek suggests that the NCB can assist the United States with the long-wall mining technique that it must now use-perhaps by the export of specialised mining equipment. The NCB also has considerable experience of the health problems posed by noise and dust in deep mines (indeed over the past four years Britain has allocated $£ 4.5$ million to medical and engineering research connected with dust control and pneumoconiosis) so there are many areas of both mining and coal utilisation research where Britain's expertise will benefit "Project Independence". But perhaps the most important aspect of the new agreement is that it will allow ideas generated on either side of the Atlantic to be shared between both parties.

\section{Copper exploration proposed for Exmoor}

by Roger Woodham

British Kynoch Metals Ltd. has applied for planning permission to explore for copper on the borders of the Exmoor National Park in Devon. The company, jointly owned by Imperial Metal Industries and British Insulated Callender's Cables, is thinking in terms of scout drilling of ten holes less than 350 feet deep to start with, but would ultimately seek permission to re-establish a mining operation in the area if things turn out well.

The first thing to be said is that open-cast mining is out of the question because of the nature of the mineralisation. The metal ores in the region are in lensoid bodies that are relatively narrow and lie en echelon. There is not the large extent of relatively poor grade ore (less than $1 \%$ ) that makes open-cast mining attractive.

British Kynoch is hoping to prospect on "a few square miles" of the Stucley estate at Heasley Mill in the North Molton area of Devon. This part of the estate includes several old workings, in particular the Bamfylde Mine which was used intermittently between the early eighteenth century and 1884 . Its output was never very great by today's standards, however-between 1860 and 1881 it produced 5,000 tons of copper ore, the grade of which may have been $17 \%$ or so locally but was probably more like $5-7 \%$ overall. The mine goes down 900 feet and the main vein is some 2,000 feet long.

$\mathrm{Mr}$ P. F. A. Loffler, Managing Director of British Kynoch, said last week that geochemical and geophysical surveys had provided "some encouragement". These methods are, however, no substitute for drilling and examining a core because copper can find its way into the soil from artificial sources and the detection by geophysical methods of conducting material at depth may indicate no more than the presence of iron ore or graphite, hardly a prize for any mining concern.

$\mathrm{Mr}$ Loffler said that as the area is well wooded and made up of valleys and combes, the operations could easily be screened. His company has declared that the "visual impact of equipment, plant and offices would be minimal" in the event that mining was started again and that no local smelting is contemplated.

Local reaction is hard to gauge at present because nobody has had time to investigate fully the implications of the planning application. There is, however, general relief that open-cast operations are not being considered for the site. 